\title{
PENGARUH WAKTU APLIKASI DAN DOSIS PUPUK NPK TERHADAP PERTUMBUHAN DAN HASIL PADI GOGO (Oryza sativa L.)
}

\author{
M. Azhari Prabukesuma, Herawati Hamim \& Niar Nurmauli \\ Jurusan Agroteknologi, Fakultas Pertanian Universitas Lampung \\ Jl. Prof. Soemantri Brodjonegoro, No.1 Bandar Lampung 35145 \\ E-mail:m.azhaaari@gmail.com
}

\begin{abstract}
ABSTRAK
Penelitian bertujuan untuk mengetahui pengaruh: perbedaan waktu aplikasi pupuk NPK terhadap pertumbuhan dan hasil padi gogo; perbedaan dosis pupuk NPK terhadap pertumbuhan dan hasil padi gogo; interaksi antara waktu aplikasi pupuk dan dosis pupuk terhadap pertumbuhan dan hasil padi gogo. Penelitian dilaksanakan pada bulan Juni 2013 sampai Oktober 2013 di Kabupaten Lampung Selatan. Penelitian menggunakan Rancangan Acak Kelompok (RAK) faktorial 3 x 4. Faktor pertama adalah waktu aplikasi pupuk NPK saat tanam $\left(\mathrm{A}_{1}\right)$, saat tanam + awal berbunga $\left(\mathrm{A}_{2}\right)$, saat tanam + awal berbunga + berbunga penuh $\left(\mathrm{A}_{3}\right)$ dan faktor kedua adalah dosis pupuk NPK $100 \mathrm{~kg} \mathrm{ha}^{-1}\left(\mathrm{P}_{1}\right), 200 \mathrm{~kg} \mathrm{ha}^{-1}\left(\mathrm{P}_{2}\right), 300 \mathrm{~kg} \mathrm{ha}^{-1}\left(\mathrm{P}_{3}\right), 400 \mathrm{~kg} \mathrm{ha}^{-1}\left(\mathrm{P}_{4}\right)$. Homogenitas data diuji dengan uji Barllet, sifat kemenambahan data diuji dengan uji Tukey dan jika asumsi terpenuhi data dianalisis dengan sidik ragam. Pemisahan nilai tengah menggunakan orthogonal polynomial pada taraf $5 \%$. Hasil penelitian menunjukkan bahwa: waktu aplikasi pupuk $\mathrm{A}_{1}$ menghasilkan anakan produktif yang lebih tinggi daripada waktu aplikasi $\mathrm{A}_{2}$. Waktu aplikasi pupuk $\mathrm{A}_{2}$ meningkatkan gabah total 0,212 butir setiap penambahan $1 \mathrm{~kg}$ pupuk NPK sampai dosis pupuk 400 $\mathrm{kg} \mathrm{NPK} \mathrm{ha}{ }^{-1}$, menghasilkan gabah isi 255,4 butir dan bobot kering gabah per hektar lebih tinggi 0,364 $\mathrm{t} \mathrm{ha}^{-1}$ daripada waktu aplikasi $A_{1}$. Waktu aplikasi pupuk $A_{3}$ menurunkan gabah total dan bobot kering gabah masing-masing 0,225 butir dan 0,007 gr setiap penambahan $1 \mathrm{~kg}$ pupuk NPK sampai dosis pupuk $400 \mathrm{~kg} \mathrm{NPK} \mathrm{ha}^{-1}$; berbagai taraf dosis pupuk NPK yang diberikan memberikan perbedaan pada parameter pengamatan tinggi tanaman, anakan produktif, panjang malai, gabah isi, gabah total, bobot 100 butir, bobot kering gabah dan bobot kering gabah per hektar; waktu aplikasi pupuk NPK terbaik adalah aplikasi pupuk $\mathrm{A}_{2}$ dengan dosis pupuk 231,67 $\mathrm{kg}^{\mathrm{NPK} \mathrm{ha}} \mathrm{h}^{-1}$ memberikan bobot kering gabah per hektar 2,609 $\mathrm{tha}^{-1}$.
\end{abstract}

Kata kunci: dosis pupuk, padi gogo, pupuk NPK, waktu aplikasi pupuk.

\section{PENDAHULUAN}

Dalam pembangunan perekonomian di Indonesia komoditi padi mempunyai peranan yang sangat penting, karena beras merupakan bahan makanan pokok bagi 95\% penduduk Indonesia (Kiswanto dkk., 2003). Pemerintah telah melakukan berbagai upaya untuk memenuhi kebutuhan beras Nasional seperti penerapan teknologi pada lahan sawah irigasi. Namun penerapan teknologi tersebut tidak seimbang dengan perluasan lahan. Setiap tahun terjadi konversi lahan baik di Pulau Jawa maupun diluar Pulau Jawa. Selama ini andalan produksi padi nasional terfokus pada lahan sawah irigasi terutama di Pulau Jawa, dengan terjadinya konversi lahan sawah ke kegiatan non pertanian, maka pengembangan lahan kering harus dioptimalkan (Sujitno dkk., 2010).

Potensi lahan kering di Indonesia merupakan sumberdaya pertanian terbesar dengan luasan mencapai 148 juta ha (Abdurrachman dkk., 2005). Menurut Sukarman dan Suharta (2010), luas lahan kering yang sesuai untuk tanaman semusim diperkirakan mencapai 25,09 juta ha. Akan tetapi sumbangan lahan kering yang tersebar di berbagai pulau Indonesia masih sangat terbatas hanya terpusat di Pulau Jawa (Suryana, 2008).

Pada lahan kering, padi gogo dapat beradaptasi dengan baik dan memiliki toleransi terhadap tanah masam yang mengandung aluminium (Barbosa dan Yamada, 2002). Dibandingkan padi sawah yang biaya produksinya cukup tinggi, padi gogo bisa menjadi alternatif sebagai pemasok kebutuhan beras nasional, namun demikian potensi lahan kering tersebut tidak sesuai dengan produktivitas padi gogo nasional yang baru mencapai 2,56 ton ha ${ }^{-1}$, jauh dari produksi padi sawah yang mencapai 4,78 ton ha-1 (Badan Pusat Statistik, 2012). Sampai saat ini,kontribusi produksi padi gogo masih rendah hanya sekitar 5-6\% (Puslitbangtan,2005). Luas panen padi gogo di Pulau Sumatera adalah sebesar 301.367 ha masih lebih sedikit dibandingkan Pulau Jawa yang mencapai 357.333 ha (Yusuf dan Yardha, 2011).

Dari penelitian yang dilakukan Sirappa dan Waas (2009) menunjukkan bahwa, peningkatan hasil tanaman padi dapat dilakukan dengan penggunaan varietas unggul dan pemupukan yang seimbang. Hasil penelitian Yusuf dan Yardha (2011), menunjukkan bahwa pemberian 
pupuk dengan dosis $300 \mathrm{~kg}$ NPK ha ${ }^{-1}$ dapat meningkatkan produksi padi gogo. Sedangkan hasil penelitian Pirngadi dkk. (2007), menunjukkan bahwa pemupukan Nitrogen untuk padi gogo berbagai varietas yang sesuai adalah $90 \mathrm{~kg} \mathrm{~N} \mathrm{ha}^{-1}$ atau setara dengan 195,6 kg Urea. Kementan (2014) memberikan dosis acuan pemupukan NPK majemuk untuk tanaman padi adalah 200-300 kg ha-1. Untuk waktu aplikasi pupuk, hasil penelitian Suryana (2012) menyatakan waktu aplikasi pupuk bertahap (1 MST, 3 MST, dan saat berbunga penuh) juga dapat meningkatkan hasil pada tanaman kedelai.

Tujuan penelitian ini adalah untuk mengetahui pengaruh: perbedaan waktu aplikasi pupuk NPK terhadap pertumbuhan dan hasil padi gogo; perbedaan dosis pupuk NPK terhadap pertumbuhan dan hasil padi gogo; interaksi antara waktu aplikasi pupuk dan dosis pupuk terhadap pertumbuhan dan hasil padi gogo.

\section{BAHAN DAN METODE}

Penelitian ini dilakukan di lahan kering Desa Bataranila Kecamatan Natar Kabupaten Lampung Selatan mulai bulan Juni 2013 sampai Oktober 2013 dan Laboratorium Agronomi Fakultas Pertanian Universitas Lampung, Bandar Lampung. Penelitian menggunakan Rancangan Acak Kelompok (RAK) faktorial 3 x 4 . Faktor pertama adalah waktu aplikasi pupuk NPK saat tanam $\left(\mathrm{A}_{1}\right)$, saat tanam + awal berbunga $\left(\mathrm{A}_{2}\right)$, saat tanam + awal berbunga + berbunga penuh $\left(\mathrm{A}_{3}\right)$ dan faktor kedua adalah dosis pupuk NPK $100 \mathrm{~kg} \mathrm{ha}^{-1}\left(\mathrm{P}_{1}\right)$, $200 \mathrm{~kg} \mathrm{ha}^{-1}\left(\mathrm{P}_{2}\right), 300 \mathrm{~kg} \mathrm{ha}^{-1}\left(\mathrm{P}_{3}\right), 400 \mathrm{~kg} \mathrm{ha}^{-1}\left(\mathrm{P}_{4}\right)$, yang diulang tiga kali. Lahan dibersihkan dari tanaman liar dan sisa-sisa akar, dicangkul sedalam $\pm 20 \mathrm{~cm}$ dan dibuat plot berukuran $2 \mathrm{~m} \mathrm{x} 4 \mathrm{~m}$ sebanyak 42 buah. Jarak antarplot $50 \mathrm{~cm}$ dan jarak antarulangan $100 \mathrm{~cm}$. Varietas yang digunakan adalah varietas Ciherang. Benih padi ditanam secara tugal langsung dilahan pada jarak tanam $20 \mathrm{~cm}$ x $20 \mathrm{~cm}$, dengan dua benih per lubang tanam. Pemberian pupuk majemuk NPK Nitrophoska dengan kandungan $\mathrm{N}: \mathrm{P}: \mathrm{K}$ adalah $15: 15: 15$, diberikan berdasarkan waktu aplikasi dan dosis sesuai dengan perlakuan. Penyiraman dilakukan tidak terjadwal bergantung pada keadaan lapangan. Sedangkan untuk penyiangan gulma dilakukan pada saat 4 MST, 8 MST dan 12 MST secara mekanis dengan menggunakan cangkul, sabit atau koret. Pengendalian Hama dan Penyakit dilakukan setiap 4 minggu dengan menggunakan Fastac dan Dithane M-45. Untuk pemanenan dilakukan setelah bulir menguning kira-kira 90\% dan daun sudah mengering, setelah itu dirontokan lalu diukur kadar airnya dengan menggunakan alat moisture tester.

\section{HASIL DAN PEMBAHASAN}

Pada aplikasi satu kali (saat tanam) dengan dosis 188,75 - $274 \mathrm{~kg}^{\mathrm{NPK}} \mathrm{ha}^{-1}$ dapat meningkatkan tinggi tanaman, anakan produktif, panjang malai, dan bobot kering gabah per hektar (Tabel 1). Namun pada bobot kering brangkasan mengalami penurunan 0,016 gr setiap penambahan $1 \mathrm{~kg}$ NPK ha-1. Sedangkan pada parameter pengamatan gabah isi, gabah hampa, gabah total, persen gabah hampa, bobot 100 butir dan bobot kering gabah tidak berbeda. Hal ini diduga karena pupuk yang diberikan dengan dosis tersebut mampu memenuhi kebutuhan unsur hara untuk pertumbuhan tanaman. Hal tersebut sesuai dengan hasil penelitian Permadi dkk., (2003) bahwa pupuk NPK Badak (20-10-10) dengan takaran $250 \mathrm{~kg} \mathrm{ha}^{-1}$ untuk tanaman padi varietas Way Apo Buru mendapatkan hasil 7,11 $\mathrm{t} \mathrm{ha}^{-1}$.

Pada aplikasi dua kali (saat tanam+awal berbunga) dengan dosis 191,3 - 246,32 kg NPK ha-1 dapat meningkatkan anakan produktif, gabah isi, dan bobot kering gabah per hektar. Sedangkan setiap penambahan $1 \mathrm{~kg}$ NPK ha-1 dapat meningkatkan gabah total 0,2129 butir. Namun pada parameter pengamatan tinggi tanaman, panjang malai, bobot kering brangkasan, gabah hampa, persen gabah hampa, bobot 100 butir, dan bobot kering gabah tidak berbeda. Hal ini menunjukkan bahwa pupuk yang diberikan mampu meningkatkan pertumbuhan tanaman pada fase vegetatif maupun generatif. Unsur N, P dan $\mathrm{K}$ dalam perlakuan pupuk diserap oleh tanaman dan digunakan untuk proses metabolisme di dalam tanaman. Menurut Sutedjo dan Kartasapoetra (2002), bahwa untuk pertumbuhan vegetatif tanaman sangat diperlukan unsur hara seperti $\mathrm{N}, \mathrm{P}, \mathrm{K}$ dan unsur lainnnya dalam jumlah yang cukup dan seimbang. Pernyataan Lakitan (1996) mendukung bahwa saat pertumbuhan reproduktif tanaman membutuhkan unsur N, P dan K. Hal ini sesuai dengan penelitian Saragih dkk. (2013) tentang waktu aplikasi pupuk pada tanaman jagung, yaitu aplikasi pupuk 2 kali (1 MST dan awal berbunga) sudah meningkatkan hasil jagung sebesar 10,65 $\mathrm{t} \mathrm{ha}^{-1}$.

Pada aplikasi tiga kali (saat tanam+awal berbunga+berbunga penuh) setiap penambahan $1 \mathrm{~kg}$ NPK ha ${ }^{-1}$ meningkatkan tinggi tanaman $0,019 \mathrm{~cm}$, bobot kering brangkasan $0,014 \mathrm{~g}$, dan gabah isi 0,5 butir. Namun pada gabah total menurun 0,225 butir dan bobot kering gabah menurun $0,0077 \mathrm{~g}$ setiap penambahan 1 $\mathrm{kg} \mathrm{NPK} \mathrm{ha}{ }^{-1}$. Sedangkan pada parameter pengamatan anakan produktif, panjang malai, gabah hampa, persen 
Tabel 1. Pengaruh waktu aplikasi dan dosis pupuk terhadap variabel pengamatan tinggi tanaman, anakan produktif, panjang malai, bobot kering brangkasan, dan gabah isi

\begin{tabular}{|c|c|c|c|c|c|c|c|c|c|c|}
\hline \multirow{2}{*}{ Perbandingan } & \multicolumn{10}{|c|}{ F hit (Signifikansi) } \\
\hline & \multicolumn{2}{|l|}{ TT } & \multicolumn{2}{|l|}{ AP } & \multicolumn{2}{|l|}{ PM } & \multicolumn{2}{|l|}{$\mathrm{BKB}$} & \multicolumn{2}{|l|}{ GI } \\
\hline \multicolumn{11}{|c|}{ Pengaruh Pupuk Majemuk (M) } \\
\hline $\mathrm{C}_{1}=\mathrm{A}_{1} \mathrm{vs} \mathrm{A}_{2}, \mathrm{~A}_{3}$ & 3,326 & tn & 0,000 & tn & 1,311 & $\operatorname{tn}$ & 0,580 & tn & $4,875(+)$ & $*$ \\
\hline $\mathrm{C}_{2}=\mathrm{A}_{2}$ vs $\mathrm{A}_{3}$ & $7,920(-)$ & $*$ & 0,102 & tn & $9,111(+)$ & $*$ & 1,368 & tn & 1,414 & tn \\
\hline \multicolumn{11}{|c|}{ Pengaruh Dosis (D) } \\
\hline $\mathrm{C}_{3}=\mathrm{P}$ Linier & 3,886 & tn & 4,097 & tn & 0,480 & $\operatorname{tn}$ & 0,725 & tn & $9,544(-)$ & $*$ \\
\hline $\mathrm{C}_{4}=\mathrm{P}$ Kuadratik & 0,479 & tn & $6,786(-)$ & $*$ & $7,541(-)$ & $*$ & 2,898 & tn & 0,773 & tn \\
\hline \multicolumn{11}{|c|}{ Persitindakan M x D } \\
\hline $\mathrm{C}_{5}=\mathrm{C}_{1} \times \mathrm{C}_{3}$ & 0,372 & tn & $9,479(+)$ & $*$ & 0,389 & $\operatorname{tn}$ & $10,105(+)$ & $*$ & 1,229 & tn \\
\hline $\mathrm{C}_{6}=\mathrm{C}_{1} \times \mathrm{C}_{4}$ & $11,316(+)$ & $*$ & $4,390(+)$ & $*$ & $8,925(+)$ & $*$ & 0,892 & tn & 0,098 & tn \\
\hline $\mathrm{C}_{7}=\mathrm{C}_{2} \times \mathrm{C}_{3}$ & $4,608(+)$ & * & $5,627(+)$ & $*$ & 0,149 & tn & $6,971(+)$ & $*$ & $13,574(-)$ & $*$ \\
\hline $\mathrm{C}_{8}=\mathrm{C}_{2} \times \mathrm{C}_{4}$ & 0,755 & tn & $9,926(+)$ & $*$ & 0,030 & $\operatorname{tn}$ & $4,587(+)$ & $*$ & $5,103(-)$ & $*$ \\
\hline \multicolumn{11}{|c|}{ Tanggapan padi gogo terhadap waktu aplikasi pada dosis pupuk } \\
\hline $\mathrm{A}_{1}=\mathrm{P}$-Linier & 2,677 & tn & $13,560(-)$ & $*$ & 0,012 & tn & $9,530(-)$ & $*$ & 0,772 & tn \\
\hline $\mathrm{A}_{1}=\mathrm{P}-\mathrm{Kuadratik}$ & $9,898(-)$ & $*$ & $10,334(-)$ & $*$ & $16,198(-)$ & $*$ & 3,077 & tn & 0,064 & tn \\
\hline $\mathrm{A}_{2}=\mathrm{P}$-Linier & 0,395 & tn & 2,525 & tn & 0,146 & tn & 1,125 & tn & 0,136 & tn \\
\hline $\mathrm{A}_{2}=\mathrm{P}-\mathrm{Kuadratik}$ & 0,129 & tn & $8,273(-)$ & $*$ & 0,238 & tn & 3,365 & tn & $4,986(+)$ & $*$ \\
\hline $\mathrm{A}_{3}=\mathrm{P}$-Linier & $5,794(+)$ & $*$ & 3,117 & tn & 0,860 & tn & $7,146(+)$ & $*$ & $23,439(-)$ & $*$ \\
\hline $\mathrm{A}_{3}=\mathrm{P}-$ Kuadratik & 2,523 & tn & 2,494 & tn & 0,059 & tn & 0,841 & tn & 0,925 & tn \\
\hline \multicolumn{11}{|c|}{ Pengaruh dosis pupuk pada waktu aplikasi } \\
\hline$P_{1}=A_{1}$ vs $A_{2}, A_{3}$ & $7,322(+)$ & $*$ & 0,766 & tn & 0,159 & tn & 2,025 & tn & 3,302 & tn \\
\hline$P_{1}=A_{2}$ vs $A_{3}$ & $5,443(-)$ & $*$ & 0,102 & tn & 1,904 & tn & 3,096 & tn & 2,820 & tn \\
\hline $\mathrm{P}_{2}=\mathrm{A}_{1}$ vs $\mathrm{A}_{2}, \mathrm{~A}_{3}$ & 0,067 & tn & $4,684(-)$ & $*$ & 3,580 & tn & 0,138 & tn & 3,084 & tn \\
\hline $\mathrm{P}_{2}=\mathrm{A}_{2} \mathrm{vs} \mathrm{A}_{3}$ & $6,555(-)$ & $*$ & 3,365 & tn & 1,458 & tn & 0,677 & tn & $11,019(+)$ & $*$ \\
\hline $\mathrm{P}_{3}=\mathrm{A}_{1} \mathrm{vs} \mathrm{A}_{2}, \mathrm{~A}_{3}$ & 3,233 & tn & 0,005 & tn & $5,020(-)$ & $*$ & 0,035 & tn & 0,019 & tn \\
\hline$P_{3}=A_{2} v_{s} A_{3}$ & 1,261 & tn & 2,673 & tn & 2,685 & tn & $6,193(-)$ & $*$ & 0,017 & tn \\
\hline $\mathrm{P}_{4}=\mathrm{A}_{1}$ vs $\mathrm{A}_{2}, \mathrm{~A}_{3}$ & $6,159(+)$ & $*$ & $8,822(+)$ & $*$ & 2,085 & tn & $9,792(+)$ & $*$ & 0,495 & tn \\
\hline $\mathrm{P}_{4}=\mathrm{A}_{2} \mathrm{vs} \mathrm{A}_{3}$ & 0,151 & tn & $9,926(+)$ & $*$ & $3,280(+)$ & $*$ & $7,461(+)$ & $*$ & $7,558(-)$ & $*$ \\
\hline
\end{tabular}

Keterangan: * (berbeda nyata pada taraf nyata 5\%), tn (tidak berbeda nyata pada taraf nyata $5 \%$ ) $\mathrm{A}_{1}$ (waktu aplikasi pupuk pada saat tanam), $\mathrm{A}_{2}$ (waktu aplikasi pupuk saat tanam + awal berbunga), $\mathrm{A}_{3}$ (waktu aplikasi pupuk saat tanam + awal berbunga + berbunga penuh), $\mathrm{P}_{1}\left(\right.$ dosis pupuk NPK $\left.100 \mathrm{~kg} \mathrm{ha}^{-1}\right), \mathrm{P}_{2}$ (dosis pupuk NPK $200 \mathrm{~kg} \mathrm{ha}^{-1}$ ), $\mathrm{P}_{3}$ (dosis pupuk NPK $\left.300 \mathrm{~kg} \mathrm{ha}^{-1}\right), \mathrm{P}_{4}$ (dosis pupuk NPK $400 \mathrm{~kg} \mathrm{ha}^{-}$ ${ }^{1}$ ), TT (tinggi tanaman), AP (anakan produktif), PM (panjang malai), BKB (bobot kering brangkasan), GI (gabah isi), dan (+) atau (-) adalah selisih antar perlakuan.

gabah hampa, bobot 100 butir dan bobot kering gabah per hektar tidak berbeda (Tabel 2, Gambar 1). Hal ini diduga karena selama fase awal tanaman berbunga dan berbunga penuh akan terjadi pemacuan pengisian bulir dan pematangan bulir padi gogo. Poulton dkk., (1989), menyatakan bahwa tanaman dalam proses metabolismenya sangat ditentukan oleh ketersediaan unsur hara terutama unsur hara makro primer yaitu $\mathrm{N}$, $\mathrm{P}$, dan $\mathrm{K}$ dalam jumlah yang cukup dan seimbang, baik pada fase pertumbuhan vegetatif, maupun fase generatif. Sukristiyonubowo dan Tuherkih (2009), menyatakan bahwa hara dari pupuk NPK dimanfaatkan 
Tabel 2. Pengaruh waktu aplikasi dan dosis pupuk terhadap variabel pengamatan gabah hampa, gabah total, persen gabah hampa, bobot 100 butir, bobot kering gabah, dan bobot kering gabah per hektar

\begin{tabular}{|c|c|c|c|c|c|c|c|c|c|c|c|}
\hline \multirow{2}{*}{ Perbandingan } & \multicolumn{11}{|c|}{ F hit (Signifikansi) } \\
\hline & $\mathrm{GH}$ & \multicolumn{2}{|l|}{ GT } & \multicolumn{2}{|c|}{ PGH } & \multicolumn{2}{|l|}{ B100 } & \multicolumn{2}{|l|}{ BKG } & \multicolumn{2}{|c|}{ BKGPH } \\
\hline \multicolumn{12}{|c|}{ Pengaruh Pupuk Majemuk (M) } \\
\hline $\mathrm{C}_{1}=\mathrm{A}_{1} \mathrm{vs} \mathrm{A}_{2}, \mathrm{~A}_{3}$ & $1,593 \mathrm{tn}$ & 2,613 & tn & 0,197 & $\operatorname{tn}$ & 2,344 & tn & $5,339(+)$ & $*$ & 0,008 & tn \\
\hline $\mathrm{C}_{2}=\mathrm{A}_{2} \mathrm{vs} \mathrm{A}_{3}$ & $3,071 \mathrm{tn}$ & 0,000 & tn & 0,038 & $\operatorname{tn}$ & $6,227(+)$ & $*$ & 2,679 & tn & $4,688(+)$ & $*$ \\
\hline \multicolumn{12}{|l|}{ Pengaruh Dosis (D) } \\
\hline $\mathrm{C}_{3}=\mathrm{P}$ Linier & 0,457 tn & 0,427 & tn & 1,032 & $\operatorname{tn}$ & 0,002 & tn & $5,134(-)$ & $*$ & $9,052(-)$ & $*$ \\
\hline $\mathrm{C}_{4}=\mathrm{P}$ Kuadratik & 0,460 tn & 0,061 & tn & 0,459 & $\operatorname{tn}$ & 0,341 & tn & 0,508 & tn & $14,368(-)$ & $*$ \\
\hline \multicolumn{12}{|c|}{ Persiti ndakan M x D } \\
\hline $\mathrm{C}_{5}=\mathrm{C}_{1} \times \mathrm{C}_{3}$ & $2,601 \mathrm{tn}$ & 0,557 & tn & 1,476 & $\operatorname{tn}$ & 0,888 & tn & 0,597 & tn & 0,008 & tn \\
\hline $\mathrm{C}_{6}=\mathrm{C}_{1} \times \mathrm{C}_{4}$ & 0,020 tn & 1,246 & tn & 2,897 & $\operatorname{tn}$ & 0,002 & tn & 1,796 & tn & 0,303 & tn \\
\hline $\mathrm{C}_{7}=\mathrm{C}_{2} \times \mathrm{C}_{3}$ & $0,542 \mathrm{tn}$ & $12,004(-)$ & $*$ & 3,960 & $\operatorname{tn}$ & 1,106 & tn & $14,520(-)$ & $*$ & $22,843(+)$ & $*$ \\
\hline $\mathrm{C}_{8}=\mathrm{C}_{2} \times \mathrm{C}_{4}$ & 3,524 tn & 1,980 & tn & 0,611 & tn & 0,014 & tn & $4,854(-)$ & $*$ & $14,730(+)$ & $*$ \\
\hline \multicolumn{12}{|c|}{ Tanggapan padi gogo terhadap waktu aplikasi pada dosis pupuk } \\
\hline $\mathrm{A}_{1}=\mathrm{P}$-Linier & - & 0,974 & tn & - & & - & & 0,458 & tn & 2,775 & tn \\
\hline $\mathrm{A}_{1}=\mathrm{P}-\mathrm{Ku}$ adratik & - & 0,590 & tn & - & & - & & 2,267 & tn & $6,958(-)$ & $*$ \\
\hline $\mathrm{A}_{2}=\mathrm{P}-$ Linier & - & $5,652(+)$ & $*$ & - & & - & & 1,146 & tn & $26,546(-)$ & $*$ \\
\hline $\mathrm{A}_{2}=\mathrm{P}-\mathrm{Ku}$ adratik & - & 2,541 & tn & - & & - & & 2,868 & tn & $21,880(-)$ & $*$ \\
\hline $\mathrm{A}_{3}=\mathrm{P}-$ Linier & - & $6,362(-)$ & $*$ & - & & - & & $18,646(+)$ & $*$ & 2,582 & tn \\
\hline $\mathrm{A}_{3}=\mathrm{P}-\mathrm{Ku}$ adratik & - & 0,157 & tn & - & & - & & 2,023 & tn & 0,563 & tn \\
\hline \multicolumn{12}{|c|}{ Pengaruh dosis pupuk pada waktu aplikasi } \\
\hline $\mathrm{P}_{1}=\mathrm{A}_{1}$ vs $\mathrm{A}_{2}, \mathrm{~A}_{3}$ & - & 0,604 & tn & - & & - & & 3,955 & tn & 0,003 & tn \\
\hline $\mathrm{P}_{1}=\mathrm{A}_{2}$ vs $\mathrm{A}_{3}$ & - & 2,165 & tn & - & & - & & $4,509(+)$ & $*$ & 0,410 & tn \\
\hline $\mathrm{P}_{2}=\mathrm{A}_{1}$ vs $\mathrm{A}_{2}, \mathrm{~A}_{3}$ & - & 0,121 & tn & - & & - & & 2,969 & tn & 0,522 & tn \\
\hline $\mathrm{P}_{2}=\mathrm{A}_{2}$ vs $\mathrm{A}_{3}$ & - & 3,860 & tn & - & & - & & $10,372(-)$ & $*$ & 0,358 & tn \\
\hline $\mathrm{P}_{3}=\mathrm{A}_{1} \mathrm{vs} \mathrm{A}_{2}, \mathrm{~A}_{3}$ & - & 0,023 & tn & - & & - & & 0,566 & tn & 1,854 & tn \\
\hline $\mathrm{P}_{3}=\mathrm{A}_{2} \mathrm{vs} \mathrm{A}_{3}$ & - & 0,289 & tn & - & & - & & 0,384 & tn & 1,155 & tn \\
\hline $\mathrm{P}_{4}=\mathrm{A}_{1} \mathrm{vs} \mathrm{A}_{2}, \mathrm{~A}_{3}$ & - & 3,823 & tn & - & & - & & 2,762 & tn & 0,263 & tn \\
\hline $\mathrm{P}_{4}=\mathrm{A}_{2} \mathrm{vs} \mathrm{A}_{3}$ & - & $8,175(-)$ & $*$ & - & & - & & $7,235(-)$ & $*$ & $44,134(+)$ & $*$ \\
\hline
\end{tabular}

Keterangan: * (berbeda nyata pada taraf nyata $5 \%$ ), tn (tidak berbeda nyata pada taraf nyata $5 \%$ ) $\mathrm{A}_{1}$ (waktu aplikasi pupuk pada saat tanam), $\mathrm{A}_{2}$ (waktu aplikasi pupuk saat tanam + awal berbunga), $\mathrm{A}_{3}$ (waktu aplikasi pupuk saat tanam + awal berbunga + berbunga penuh), $\mathrm{P}_{1}$ (dosis pupuk NPK $\left.100 \mathrm{~kg} \mathrm{ha}^{-1}\right), \mathrm{P}_{2}$ (dosis pupuk NPK $200 \mathrm{~kg} \mathrm{ha}^{-1}$ ), $\mathrm{P}_{3}$ (dosis pupuk NPK $300 \mathrm{~kg} \mathrm{ha}^{-1}$ ), $\mathrm{P}_{4}$ (dosis pupuk NPK $400 \mathrm{~kg} \mathrm{ha}^{-}$ $\left.{ }^{1}\right)$, GH (gabah hampa), GT (gabah total), PGH (persen gabah hampa), B100 (bobot 100 butir), BKG (bobot kering gabah), BKGPH (bobot kering gabah per hektar), dan (+) atau (-) adalah selisih antar perlakuan.

tanaman untuk pertumbuhan tanaman sama baiknya dengan hara yang berasal dari pupuk tunggal Urea, SP36, dan $\mathrm{KCl}$.

Parameter pengamatan gabah hampa dan persen gabah hampa tidak berbeda disetiap perlakuan yang diberikan. Hal ini diduga karena pada saat pengisian biji tanaman padi gogo kekurangan air. Sesuai dengan data curah hujan periode penanaman bulan Juni hingga Oktober 2013 bahwa curah hujan pada saat pertanaman rendah. Menurut Chang, dkk. (1982) tanaman padi yang mengalami cekaman air pada fase-fase pembungaan dan pengisian biji menyebabkan berkurangnya komponen- 


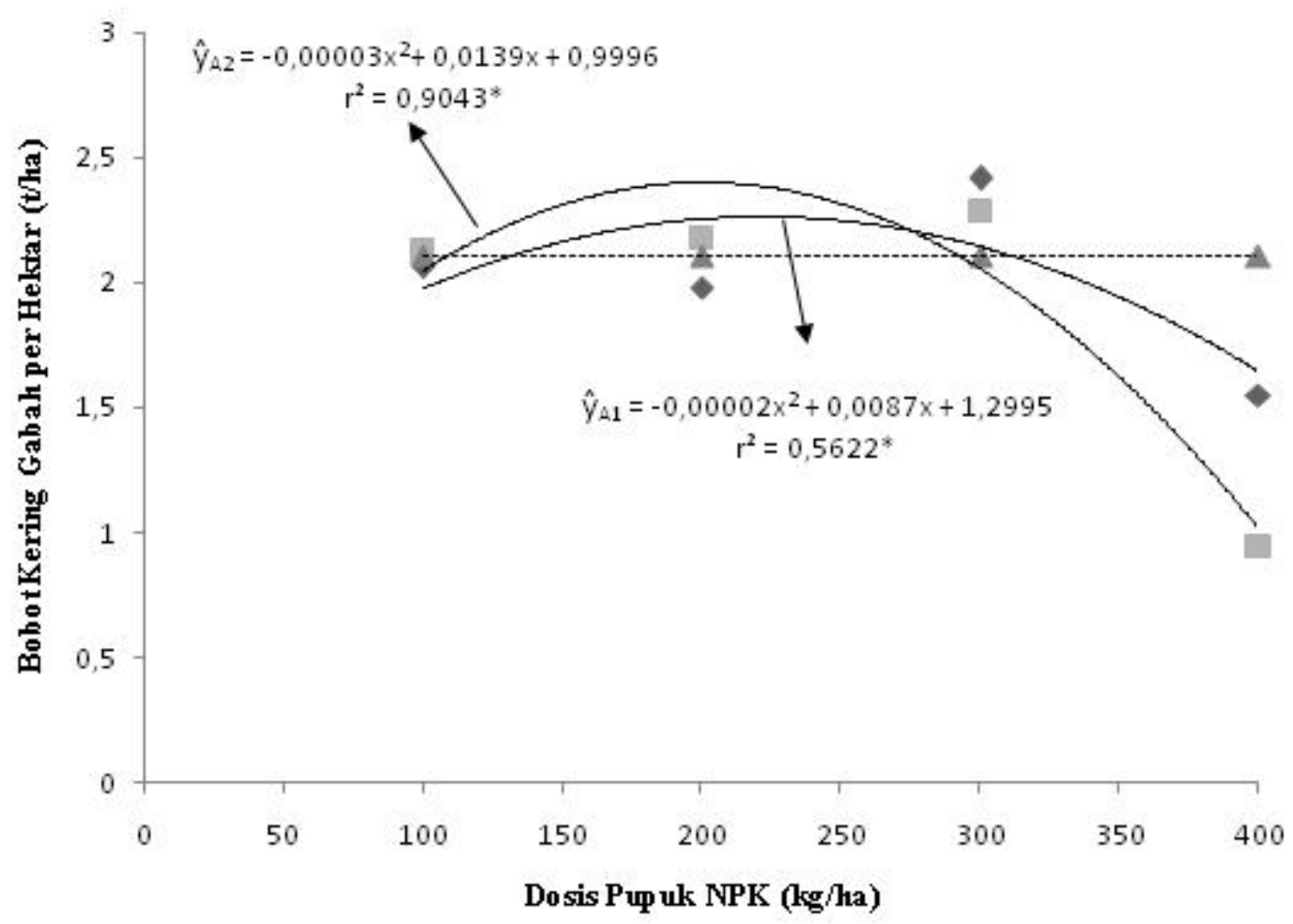

Gambar 1. Pengaruh waktu aplikasi pada peningkatan dosis pupuk terhadap bobot kering gabah per hektar. $\bullet \mathrm{A} 1=$ saat tanam, $\square \mathrm{A} 2=$ saat tanam + awal berbunga, $\Delta \mathrm{A} 3=$ saat tanam + awal berbunga + berbunga penuh.

komponen hasil. Selain itu apabila terjadi cekaman air pada masa pembungaan dan pengisian biji maka dapat mempengaruhi banyak gabah yang hampa akibat kekurangan air (Fin dan Brun, 1980). Untuk parameter bobot 100 butir juga tidak berbeda disetiap perlakuan yang diberikan. Hal ini diduga karena selain terjadi kekurangan air pada saat pengisian biji juga dipengaruhi oleh faktor genetik dari benih yang digunakan dalam pertanaman. Menurut Wibowo (2010) sifat yang berasal dari masing-masing galur maupun varietas mempengaruhi produksi tanaman yang akan dihasilkan.

Hampir semua parameter pengamatan memiliki nilai korelasi positif dengan parameter pengamatan lainnya, kecuali tinggi tanaman. Terdapat korelasi yang positif antara anakan produktif, panjang malai, bobot kering brangkasan, dan bobot kering gabah per hektar. Tanaman padi gogo yang memiliki anakan produktif yang banyak tentunya akan memiliki banyak malai untuk menghasilkan bulir padi, serta memiliki bobot kering brangkasan yang tinggi sehingga akan memberikan bobot kering gabah per hektar yang tinggi. Sedangkan parameter pengamatan gabah isi berkorelasi positif dengan gabah total, gabah hampa, persen gabah hampa, dan bobot kering gabah. Artinya gabah isi yang dihasilkan bergantung dari banyaknya jumlah gabah total, gabah hampa. Persentase gabah hampa dari tanaman juga dipengaruhi perbandingan antara gabah isi dan gabah hampa dari jumlah total gabah yang dihasilkan. Bobot kering gabah yang dihasilkan tentunya sangat bergantung dari jumlah gabah total yang dihasilkan.

Padi gogo merupakan tanaman yang sangat potensial utk dikembangkan di lahan kering. Padi gogo dapat menjadi alternatif sebagai pemasok kebutuhan beras nasional yang saat ini masih mengandalkan padi sawah. Pupuk NPK juga merupakan pupuk yang dapat digunakan sebagai pengganti pupuk tunggal. Dengan demikian kedua hal tersebut sudah semestinya dapat dikembangkan potensinya. Aplikasi pupuk satu kali (saat tanam) dengan dosis pupuk $217,5 \mathrm{~kg}$ NPK hamemberikan bobot kering gabah per hektar 2,245 $\mathrm{t} \mathrm{ha}^{-1}$. Sedangkan pada aplikasi pupuk dua kali (saat tanam + awal berbunga) dengan dosis pupuk 231,67 kg NPK ha${ }^{1}$ memberikan bobot kering gabah per hektar 2,609 $\mathrm{t}$ ha' ${ }^{1}$. Sehingga terdapat peningkatan $0,364 \mathrm{t} \mathrm{ha}^{-1}$ bila ditambahkan 14,17 kg NPK ha-1. Melihat bobot kering gabah per hektar yang dihasilkan lebih tinggi dari rerata bobot kering gabah per hektar nasional yaitu 2,56 $\mathrm{t} \mathrm{ha}^{-1}$, sudah sebaiknya petani menerapkan cara aplikasi aplikasi pupuk dua kali (saat tanam + awal berbunga) dengan dosis pupuk 231,67 $\mathrm{kg} \mathrm{NPK} \mathrm{ha}^{-1}$ dalam upaya peningkatan bobot kering gabah per hektar padi gogo. 


\section{KESIMPULAN}

Dari hasil penelitian dapat disimpulkan bahwa: waktu aplikasi pupuk satu kali (saat tanam) menghasilkan anakan produktif yang lebih tinggi daripada waktu aplikasi dua kali (saat tanam + awal berbunga). Waktu aplikasi pupuk dua kali (saat tanam + awal berbunga) meningkatkan gabah total 0,212 butir setiap penambahan $1 \mathrm{~kg}$ pupuk NPK sampai dosis pupuk $400 \mathrm{~kg}$ NPK ha- ${ }^{-1}$, menghasilkan gabah isi 255,4 butir dan bobot kering gabah per hektar lebih tinggi $0,364 \mathrm{tha}^{-1}$ daripada waktu aplikasi pupuk satu kali (saat tanam). Waktu aplikasi pupuk tiga kali (saat tanam + awal berbunga + berbunga penuh) menurunkan gabah total dan bobot kering gabah masing-masing 0,225 butir dan 0,007 gr setiap penambahan $1 \mathrm{~kg}$ pupuk NPK sampai dosis pupuk 400 kg NPK ha-1 ${ }^{-1}$ berbagai taraf dosis pupuk NPK yang diberikan memberikan perbedaan pada parameter pengamatan tinggi tanaman, anakan produktif, panjang malai, gabah isi, gabah total, bobot 100 butir, bobot kering gabah dan bobot kering gabah per hektar. Dosis pupuk $231,67 \mathrm{~kg}$ NPK ha-1 memberikan bobot kering gabah per hektar tertinggi; cara aplikasi pupuk NPK terbaik adalah aplikasi pupuk dua kali (saat tanam+awal berbunga) dengan dosis pupuk $231,67 \mathrm{~kg}$ NPK hamemberikan bobot kering gabah per hektar 2,609 $\mathrm{t} \mathrm{ha}^{-1}$.

\section{DAFTAR PUSTAKA}

Abdurachman, A., S. Sutono, dan N. Sutrisno. 2005. Teknologi Pengendalian Erosi Lahan Berlereng (dalam Teknologi Pengelolan Lahan Kering; Penyunting: Abdurachman Adimihardja dan Mapaona). Puslitanak, Badan Penelitan dan Pengembangan Pertanian. Departemen Pertanian. Bogor. Hal. 101-140.

Badan Pusat Statistik. 2012. Indonesia dalam Angka. www.bps.go.id. Jakarta.

Balai Besar Penelitian Padi. 2007. Varietas Unggul Padi Sawah 1943 - 2007. http:// bbpadi.litbang.deptan.go.id/varietas padi yang dilepas.pdf. Jakarta.

Barbosa,M.P. dan T.Yamada. 2002. Upland Rice Production in Brazil. In: Rice Production Better Crop International. 16 : 43-46.

Chang, T. T., G. C. Loresto, J. C. O'Toole, and J. L. Armenta-Sotto. 1982. Strategy and methodology of breeding rice for drought-prone areas. Drought Resistance in Crops with Emphasis on Rice. IRRI, Los Banos. Pp 217 - 272.
Finn, G. A., and W. A. Brun. 1980. Water stress effect on $\mathrm{CO} 2$ assimilation, photosynthate portioning, stomata soybean. $20: 431-434$.

Kementan. 2014. Dosis Acuan Padi. http:// cybex.deptan.go.id/lokalita/dosis-pemupukanpadi. diakses pada tanggal 8 Juli 2014 .

Kiswanto, A. Fahri dan B. Sudaryanto. 2003. Dinamika Produksi Padi Tahun 200-2001 di Provinsi Lampung. J. Teknologi Pertanian Lampung. 1 (1) : 12-23.

Lakitan, B. 1996. Fisiologi Pertumbuhan dan Perkembangan Tanaman. PT. Raja GrafindoPersada, Jakarta. 218 hal.

Minardi, S. 2002. Kajian Komposisi Pupuk NPK terhadap Hasil Beberapa Varietas Tanaman Buncis Tegak (Phaseolus vulgaris L.) di Tanah Alfisol. Sains Tanah. 2 (1): 18-24.

Permadi., K., H.M. Toha., K. Pirngadi. 2003. Pemupukan Majemuk NPK Badak (20-10-10) pada Pertumbuhan dan Hasil Padi Sawah Varietas Way Apo Buru. J.Agrivigor. 3 (2) : 113-127.

Pirngadi,K., H.M. Toha, B.Nuryanto. 2007. Pengaruh Pemupukan N pada Pertumbuhan dan Hasil padi Gogo di Dataran Sedang. Balai Besar Penelitian Tanaman Padi. J.Apresiasi Hasil Penelitian Padi 2007. 325-338.

Puslitbangtan. 2005. Peluang Menuju Swasembada Beras Berkelanjutan. J. Warta Penelitian dan Pengembangan Pertanian. 27 (5) : 12-14.

Poulton, J.E, Romeo, J.T \& Conn, E.E. 1989. Plant Nitrogen Metabolism. Recent Advances in Phytochemistry. Vol.23. New York: Plenum Press.

Sirappa,M.P dan E.D. Waas. 2009. Kajian Varietas dan Pemupukan terhadap Peningkatan Hasil Padi Sawah di Dataran Pasahari, Maluku Tengah. . J. Pengkajian dan Pengembangan Teknologi Pertanian. 12 (1) : 79-90.

Saragih, D., Herawati H., dan N. Nurmauli. 2013. Pengaruh Dosis dan Waktu Aplikasi Pupuk Urea dalam Meningkatkan Pertumbuhan dan Hasil Jagung (Zea mays, L.) Pioner 27. J.Agrotek Tropika. 1 (1) : 50-54.

Sujitno,E., T.Fahmi dan S.Teddy. 2010. Kajian Adaptasi Beberapa Varietas Unggul Padi Gogo pada Lahan Kering Dataran Rendah di Kabupaten Garut. J. Pengkajian dan Pengembangan Teknologi Pertanian. 14 (1) : 62-69. 
Sukarman dan N. Suharta. 2010. Kebutuhan lahan kering untuk kecukupan produksi pangan tahun 20102050. Analisis Sumberdaya Lahan Menuju Ketahanan Pangan Berkelanjutan. Badan Penelitian dan Pengembangan Pertanian. Kementerian Pertanian. Hal 111 - 124.

Sukristiyonubowo dan E. Tuherkih (2009). Rice production in terraced paddy field systems. $J$. Penelitian Pertanian Tanaman Pangan. 28(3): 139-147

Suryana,A. 2012. Pengaruh waktu aplikasi dan dosis pupuk majemuk NPK pada pertumbuhan dan hasil tanaman kedelai varietas grobogan.(Skripsi). Fakultas Pertanian. Universitas Lampung. Hal 36.

Suryana,A. 2008. Petunjuk Teknis Lapang. Pengelolaan Tanaman Terpadu (PTT) Padi Gogo. Badan Penelitian dan Pengembangan Pertanian. Departemen Pertanian. Hal.7.
Sutedjo, M. M., dan A.G. Kartasapoetra. 2002. Pengantar Ilmu Tanah. Rineka Cipta. Bogor. Hal 152.

Wibowo, P. 2010. Pertumbuhan dan produktivitas galur harapan padi (Oryza sativa L.) Hibrida di desa Ketaon kecamatan Banyudono Boyolali. Skripsi. Universitas Sebelas Maret. Hal 45.

Yusuf,A. dan Yardha. 2011. Uji Adaptasi Galur Harapan/ Varietas Padi Gogo pada Ekosistem Dataran Rendah di Kabupaten Deli Serdang. J.Agroteknologi. 1 (2) : 29-35. 